\title{
Qualitative Losses in Different Varieties of Lentil Caused by the Infestation of Callosobruchus chinensis
}

\author{
Suman Choudhary $^{1 *}$, M.C. Bhargava ${ }^{1}$, M.K. Yadav ${ }^{1}$, G.C. Jat ${ }^{2}$ and M.D. Choudhary ${ }^{1}$ \\ ${ }^{1}$ Department of Entomology, S.K.N. College of Agriculture, Jobner (303 329), S.K.N.A.U., \\ Jobner, Jaipur, (Rajasthan), India \\ ${ }^{2}$ Department of Entomology, Rajasthan College of Agriculture, MPUAT, \\ Udaipur, (Rajasthan), India \\ *Corresponding author
}

\section{A B S T R A C T}

\begin{tabular}{|l|}
\hline Key w or d s \\
$\begin{array}{l}\text { Callosobruchus } \\
\text { chinensis L., Lentil, } \\
\text { Physico-chemical } \\
\text { characteristics. }\end{array}$ \\
\hline Article Info \\
\hline $\begin{array}{l}\text { Accepted: } \\
23 \text { May } 2017 \\
\text { Available Online: } \\
\text { 10 June 2017 }\end{array}$ \\
\hline \hline
\end{tabular}

Investigations were carried out on Eco-friendly management of pulse beetle Callosobruchus chinensis Linnaeus on Lentil (Lens esculenta Moench) during 2014-15 at S.K.N. College of Agriculture, Jobner. Out of 10 varieties screened on the basis of physico- chemical characters against this insect, Asha and PL-01 were less susceptible and Spana, IPL-81 and L4076 were highly susceptible. However, PBW-343, L-147, RKL-60701, JL-3, RKL-607 and RKL6118 were moderate susceptible.

\section{Introduction}

Pulses the "wonderful gift of nature" play an important role both in Indian economy and diet. Pulses are traditionally recognized as an indispensable constituent of Indian diet. In India where the population is predominantly vegetarian, pulses are important as they are rich source of protein, amino acids, energy, minerals and certain vitamins. It is one of the oldest pulse crops and the most nutritious of the pulses. Lentil contains about 11per cent water, 25 per cent protein and 60 per cent carbohydrates. It is rich in calcium, iron and niacin. Lentil contributes about 6 per cent in total pulses area as well as production of India. India has the largest producer of pulses in world it has 15 lakh ha, 9.5 lakh tone production and productivity of lentil 633.33 $\mathrm{kg} / \mathrm{ha}$ (Anonymous, 2014-15a). However, among the Indian states, Rajasthan stands at first position in pulse production in 2011. The total area in Rajasthan under lentil was 30718 ha with the annual production of 26679 tonnes and productivity in Rajasthan 869 $\mathrm{kg} / \mathrm{ha}$ (Anonymous, 2014-15b).

\section{Materials and Methods}

\section{Maintenance of insect culture}

To maintain the stock culture of $C$. chinensis, the sound and healthy lentil grains of variety Sapana were cleaned and sieved to remove 
the fractions of grains or insects. These grains were conditioned at least for a week in an environmental chamber maintaining $27 \pm 2^{\circ} \mathrm{C}$ and $65 \pm 5$ per cent relative humidity to raise their moisture content. All the experiments were carried out in Completely Randomized Design with three repetitions.

\section{Grain size}

Grain size was determined by water displacement method (Ram and Singh, 1996) wherein known volume of water taken in a measuring cylinder (10 $\mathrm{ml}$ capacity) and then 100 grains were introduced. The increase in volume gave volume of 100 grains. The process was repeated thrice to get a mean volume of 100 grains which were used as an index of grain size of a variety.

\section{Grain hardness}

The grain hardness were measured by a pressure type grain hardness tester which measured the pressure (in $\mathrm{Kg}$ ) required to break single grain. Ten grains of each variety were individually tested and the average pressure required per grain was used as a measure of grain hardness.

\section{Moisture content}

The moisture content in the collected samples was determined with the help of MAC digital moisture meter as per the procedure given in the manual of the equipment.

\section{Qualitative losses}

Nutritional changes of the infested grains induced by infestation of $C$. chinensis larvae were studied for proteins and carbohydrates. For this purpose, infested wheat samples were cleaned and sieved to remove insect body parts. Cleaned grain samples of healthy and infested grains in triplicate were taken for determination of proteins and carbohydrates by following standard methods.

\section{Determination of carbohydrates}

Carbohydrates were estimated by using anthrone reagent (Hedge and Hofreiter, 1962).Weighed sample (100 mg) was taken in a tube and hydrolyse with $5 \mathrm{ml}$ of $2.5 \mathrm{~N}-\mathrm{HCl}$ by keeping it in a boiling water bath for three hrs and cooled to room temperature. It was neutralise with solid sodium carbonate until the effervescence cease. The volume was made to $100 \mathrm{ml}$ with distilled water and centrifuged. The supernatant was collected and $0.5-1 \mathrm{ml}$ aliquots were taken for analysis. The standards were prepared by taking 0.2 , $0.4,0.6,0.8$ and $1 \mathrm{ml}$ of the working standard in separate tubes. The volumes in all tubes were made to $1 \mathrm{ml}$ including the sample tubes by adding distilled water. The tube containing $1 \mathrm{ml}$ distilled water served as control. $4 \mathrm{ml}$ of anthrone reagent was added to each tube and the tubes were kept for eight minutes in a boiling water bath. The tubes were cooled rapidly and read the green to dark green colour at $630 \mathrm{~nm}$. Finally standard graph was drawn by plotting concentration of the standard on the $\mathrm{X}$-axis verses absorbance on the $\mathrm{Y}$-axis and from the graph amount of carbohydrate present in the samples were calculated.

mg of glucose
Amount of carbohydrate $=$-------- $\times 100$
Volume of test sample

\section{Determination of proteins}

Proteins were estimated by using Kjeldahl method (Balasubramanian and Sadasivam, 1987). $100 \mathrm{mg}$ of sample in a digestion tube was weighed. A pinch of catalyst mixture $\left(\mathrm{K}_{2} \mathrm{SO}_{4}+\mathrm{HgO}+\mathrm{CuSO}_{4}\right)$ and $2 \mathrm{ml}$ of concentrated sulphuric acid was added in this. The sample was digested for about half an 
hour till it became colourless. After cooling, little distilled water was added. A $100 \mathrm{ml}$ conical flask was placed containing $5 \mathrm{ml}$ of $4 \%$ boric acid solution with few drops of mixed indicator; the tip of the condenser should dip below the surface of the solution. $10 \mathrm{ml}$ of $\mathrm{NaOH}$-sodium thiosulphate solution was added to the test solution. Distillation was done for 5-7 minutes and ammonia liberated was collected and trapped in boric acid. This solution was titrated with $0.02 \mathrm{~N}$ sulphuric acid till colour change appeared. A blank was run with equal amount of distilled water. The liberated $\mathrm{N}$ content was calculated by using following formula.

$\mathrm{HCl}$ in $\mathrm{ml} \mathrm{X}$ Normality of $\mathrm{HCl} \mathrm{X} 14.04$

$\mathrm{Ng} / \mathrm{kg}=$

Weight of Sample (g)

Protein $(\%)$ is calculated multiplying by 6.25 .

\section{Results and Discussion}

\section{Grain size (Table 1)}

The grain size was lowest in Asha $(2.2 \mathrm{ml})$, which was at par with PL-01 (2.4 ml), RKL$60701(2.7 \mathrm{ml})$ and LL-147 $(2.8 \mathrm{ml})$. The highest grain size was observed in Spana (3.8 $\mathrm{ml})$, which was at par with JL-3 $(3.2 \mathrm{ml})$, RKL-607 (3.3 ml), RKL-6118 (3.4ml), L$4076(3.5 \mathrm{ml})$ and IPL-81 $(3.7 \mathrm{ml})$. No work on the varietal variation in grain size of lentil varieties, however, the present findings are in confirmation with the work of Ram and Singh (1996) who reported that grain size varied from 1.6 to $3.8 \mathrm{ml}$ in different wheat varieties.

\section{Grain hardness (Table 1 Fig. 1)}

The soft varieties Spana $(8.01 \mathrm{~kg})$ and IPL-81 $(8.18 \mathrm{~kg})$ were found highly susceptible, while harder varieties PL-01 (11.24 kg) and Asha $(11.38 \mathrm{~kg})$ were found least susceptible. These findings are just similar to the results of Ram and Singh (1996) that showed great variation in grain hardness and exhibited negative and significant correlation with susceptibility to khapra beetle.

\section{Moisture content (Table 1)}

Moisture percentage in different varieties of lentil varied from 10.50 to 12.96 , being maximum in Spana and minimum in Asha. It was found that the higher per cent of moisture induces higher infestation of grain seeds.

Table.1 Physico-chemical characteristics of lentil varieties*

\begin{tabular}{lccc}
\hline Varieties & $\begin{array}{c}\text { Size of 100 grains } \\
(\mathbf{m l})\end{array}$ & $\begin{array}{c}\text { Grain hardness } \\
(\mathbf{k g})\end{array}$ & $\begin{array}{c}\text { Moisture content } \\
(\mathbf{\%})\end{array}$ \\
\hline RKL6118 & 3.40 & 9.71 & 11.50 \\
IPL-81 & 3.70 & 8.18 & 12.84 \\
L-4076 & 3.50 & 9.36 & 12.00 \\
RKL-607 & 3.30 & 9.85 & 11.24 \\
RKL-60701 & 2.70 & 10.00 & 11.01 \\
JL-3 & 3.20 & 9.88 & 11.03 \\
SPANA & 3.80 & 8.01 & 12.96 \\
ASHA & 2.20 & 11.38 & 10.50 \\
LL-147 & 2.80 & 10.37 & 11.00 \\
PL-01 & 2.40 & 11.24 & 10.97 \\
\hline S.Em+ + & 0.25 & 0.58 & 0.37 \\
C.D. at 5\% & 0.73 & 1.73 & 1.10 \\
\hline
\end{tabular}

* Data based on three replications 
Table.2 Physico-chemical characteristics of lentil varieties*

\begin{tabular}{lccc|ccc}
\hline Varieties & \multicolumn{3}{c|}{ Carbohydrate (\%) } & \multicolumn{3}{c}{ Protein (\%) } \\
\cline { 2 - 7 } & $\begin{array}{c}\text { Healthy } \\
\text { grains }\end{array}$ & $\begin{array}{c}\text { Infested } \\
\text { grains }\end{array}$ & $\begin{array}{c}\text { Per cent } \\
\text { decrease }\end{array}$ & $\begin{array}{c}\text { Healthy } \\
\text { grains }\end{array}$ & $\begin{array}{c}\text { Infested } \\
\text { grains }\end{array}$ & $\begin{array}{c}\text { Per cent } \\
\text { increase }\end{array}$ \\
\hline RKL6118 & 75.05 & 72.10 & 3.931 & 12.45 & 12.67 & 1.767 \\
IPL-81 & 76.20 & 72.20 & 5.249 & 12.53 & 12.79 & 2.153 \\
L-4076 & 72.50 & 69.50 & 4.138 & 11.46 & 11.66 & 1.655 \\
RKL-607 & 74.05 & 71.91 & 2.890 & 11.67 & 11.86 & 1.540 \\
RKL-60701 & 73.65 & 71.65 & 2.716 & 13.01 & 13.23 & 1.611 \\
JL-3 & 74.33 & 72.20 & 2.735 & 12.16 & 12.33 & 1.482 \\
SPANA & 74.35 & 70.35 & 5.380 & 12.04 & 12.29 & 2.248 \\
ASHA & 72.98 & 71.32 & 2.275 & 11.82 & 11.99 & 1.351 \\
LL-147 & 70.00 & 68.17 & 2.614 & 12.14 & 12.30 & 1.402 \\
PL-01 & 73.77 & 72.00 & 2.399 & 11.53 & 11.68 & 1.389 \\
\hline S.Em+ & - & - & - & 0.33 & - & 0.041 \\
C.D. at 5\% & - & - & - & 0.98 & - & 0.122 \\
\hline
\end{tabular}

* Data based on three replications

\section{Determination of carbohydrates (Table 2)}

Minimum reduction to the tune of 2.27 per cent carbohydrate was observed in Asha, while maximum reduction 5.38 per cent in Spana.

The results are in conformity with the findings of Jood and Kapoor (1992) who reported that a significant reduction in carbohydrate contents of wheat, maize and sorghum when artificially infested with $T$. granarium and $R$. Dominica.

\section{Determination of proteins (Table 2)}

The result showed that protein content in different lentil varieties was increased due to infestation of $C$. chinensis. The highest increased percentage of protein was observed in the variety Spana (2.248), while lowest increase in percentage of protein was noted in Asha (1.351). Rahman (1942) and Bindra and Kumari (1975) reported protein content to be higher in susceptible varieties but Bains et al., (1971) and Singh and Agarwal (1976) found no such relationship.

\section{Acknowledgement}

The authors are grateful to Dean, S K N College of Agriculture, Head of Department of Entomology, SKN College of Agriculture, Jobner for providing necessary facilities to carry out the present investigations.

\section{References}

Anonymous 2014-15a. Agricultural Statistics at a Glance. Department of Agriculture and Cooperation, Ministry of Agriculture, Government of India.

Anonymous 2014-15b. Agricultural Statistics at a Glance. Department of Agriculture and Cooperation, Ministry of Agriculture, Government of India.

Bains S S, Baljeet Kaur and Atwal A S 1971. Relative varietal resistance in some new wheat to the attack of Trogoderma granarium Everts. Bulletin of Grain Technology, 9(3): 197-202.

Balasubramanian T and Sadasivam S 1987. Plant Foods for Human Nutrition. pp. 37-41

Bindra O S and Kumari S 1975. A study on varietal resistance in wheat to stored 
grain pests. Indian Journal of Plant Protection, 3(1): 45-51.

Hedge J E and Hofreiter B T 1962. Carbohydrate Chemistry $17 \quad$ (Eds Whistler, R L and Be Miller J N) Academic Press, New York.

Jood S and Kapoor A C1992. Biological evaluation of protein quality of wheat as affected by insect infestation. Food Chemistry, 45: 169-174.

Rahman K A 1942. Insect pests stored grain in the Punjab and their control. Indian Journal of Agricultural Sciences, 12(4):
564-587.

Ram C and Singh V S 1996. Resistance to Trogoderma granarium in wheat and associated grain characteristics. Indian Journal of Entomology, 58(1): 66-73.

Singh K and Agrawal N S 1976 Susceptibility of high yielding varieties of wheat to Sitophilus oryzae (Linn.) and Trogoderma granarium Everts. Indian Journal of Entomology, 38(4): 363-369.

\section{How to cite this article:}

Suman Choudhary, M.C. Bhargava, M.K. Yadav and Jat, G.C. 2017. Qualitative Losses in Different Varieties of Lentil Caused by the Infestation of Callosobruchus chinensis. Int.J.Curr.Microbiol.App.Sci. 6(6): 2044-2048. doi: https://doi.org/10.20546/ijcmas.2017.606.241 